\title{
CONSUMER BEHAVIOR IN THE PERSPECTIVE OF CONVENTIONAL ECONOMICS AND ISLAMIC ECONOMY
}

\author{
Pepe Iswanto \\ Institut Agama Islam Darussalam (IAID) Ciamis-Jawa Barat \\ Email: pepe.iswanto@iaid.ac.id \\ Yani Mulyani \\ Institut Agama Islam Darussalam (IAID) Ciamis-Jawa Barat \\ Husna Lailatul Qadar \\ Institut Agama Islam Darussalam (IAID) Ciamis-Jawa Barat

\begin{abstract}
Consumer behavior in the perspective of conventional economy is based on the philosophy of capitalism, so that each individual is more rational than spiritual. While in the perspective of Islamic economics, consumer behavior is based on the philosophy of God so that in every activity to meet the needs of consumers are required to always be guided by the principles of monotheism, khilafah, and also justice. In addition the authors find the existence of similarities and differences from both perspectives of the theory. The similarity between consumer behavior in carrying out consumption activity in conventional economics and Islamic economy there are three, among them in terms of understanding, philosophy base, motivation and purpose of consumption, and consumer behavior theory. The difference lies in the foundations of philosophy, the principles of consumption, the motives and purposes of consumption, the configuration of consumer needs, and the latter lies in consumer behavior. This study was conducted with the aim to know: (1) consumer behavior in conventional economic perspectives (2) consumer behavior in sharia economic perspective (3) comparison of consumer behavior in conventional economic and economic perspectives of sharia. This research method uses library research approach, because the object of study is focused on the study by conducting a review study on books, data, literatures related to the analysis of research discussion related to consumer behavior, both in economy conventional and Islamic. The results show that: (1) Consumer behavior involves the behavior of consumers, where they can illustrate the search to buy, use, evaluate and improve a product and their services. (2) The consumption behavior of Islam based on the guidance of the Qur'an and Hadith needs to be based on an enhanced rationality that integrates belief in truth that transcends this very limited human rationality. (3) Comparisons between consumer behavior in conventional economics and the declining Islamic economy, explains that there are some differences from both points of view. The first is lies in the cornerstone of the philosophy of consumer behavior. Second, related to the principle of consumption. The principle of consumption in the conventional economy there are three namely freedom, self interest, and material. Third, look at the motive and purpose of consumption.
\end{abstract}

\begin{abstract}
Abstrak
Perilaku konsumen dalam perspektif ekonomi konvensional didasarkan pada filosofi kapitalisme, sehingga setiap individu lebih rasional ketimbang spiritual. Adapun dalam perspektif ekonomi Islam, perilaku konsumen didasarkan pada falsafah Tuhan sehingga dalam setiap aktivitas memenuhi kebutuhannya, konsumen dituntut untuk selalu berpedoman pada prinsip tauhid, khilafah, dan keadilan. Selain itu penulis menemukan adanya persamaan dan perbedaan dari kedua perspektif teori tersebut.
\end{abstract}


Kesamaan perilaku konsumen dalam melakukan aktivitas konsumsi dalam ekonomi konvensional dan ekonomi Islam ada tiga, di antaranya dalam hal pemahaman, landasan filosofi, motivasi, dan tujuan konsumsi. Perbedaannya terletak pada landasan filosofi, prinsip konsumsi, motif dan tujuan konsumsi, konfigurasi kebutuhan konsumen, dan yang terakhir terletak pada perilaku konsumen. Penelitian bertujuan untuk mengetahui: (1) perilaku konsumen dalam perspektif ekonomi konvensional (2) perilaku konsumen dalam perspektif ekonomi syariah (3) perbandingan perilaku konsumen dalam perspektif ekonomi konvensional dan ekonomi syariah. Metode penelitian ini menggunakan pendekatan penelitian kepustakaan, karena objek kajian difokuskan pada kajian dengan melakukan kajian telaah terhadap buku-buku, datadata, kepustakaan yang berkaitan dengan analisis pembahasan penelitian yang berkaitan dengan perilaku konsumen, baik dalam perekonomian konvensional maupun Islam. Hasil penelitian menunjukkan bahwa: (1) Perilaku konsumen melibatkan perilaku konsumen, dimana mereka dapat menggambarkan pencarian untuk membeli, menggunakan, mengevaluasi dan meningkatkan suatu produk dan layanan mereka. (2) Perilaku konsumsi Islam berdasarkan tuntunan Al-Qur'an dan Hadits perlu didasarkan pada peningkatan rasionalitas yang mengintegrasikan keyakinan akan kebenaran yang melampaui rasionalitas manusia yang sangat terbatas ini. (3) Perbandingan antara perilaku konsumen dalam ekonomi konvensional dan ekonomi Islam yang menurun, menjelaskan bahwa ada beberapa perbedaan dari kedua sudut pandang. Yang pertama terletak pada landasan filosofi perilaku konsumen. Kedua, terkait dengan prinsip konsumsi. Prinsip konsumsi dalam ekonomi konvensional ada tiga yaitu kebebasan, kepentingan diri sendiri, dan materi. Ketiga, melihat motif dan tujuan konsumsi.

Keywords: Consumer Behavior, Islamic Economy, Conventional Economic, Capitalism, Spiritualism

\section{Introduction}

The current world economic system is secular where there is a dichotomy between religions and worldly life including in which economic activity has begun to erode. The occurrence of this decotomy occurred in the dark ages (dark ages) that occurred in Europe, at that time the power of the Catholic church is very dominant.

So this led to a movement that sought to erode the overwhelming power of the church at that time. It is this movement which eventually led to a school of thought that there must be a distinction or limitation between religious activity and the world, since the emergence of scientific thought is often considered contrary to the doctrine of the church at that time Case and Ray (199: 8).

This does not apply to Islam, because Islam does not recognize the distinction between religious and worldly sciences. It is evident that in the dark ages (dark ages) that occurred in Europe, precisely happened the golden age and glory of Islam. Where there is renewal and development of thought by Muslim scientists, even the basis of the development of scholarship to date, such as science algebra.

This, however, is never known to the world especially by the younger generation of Muslims, so that the current generation of Muslim youth does the same thing done by the West in the dark ages of dichotomy between the spiritual and temporal activities that actually make Islam increasingly dim light. As the western country progresses further away from its religion, Muslims will be left behind when leaving their religion. Economics is a discipline that explains about the process of decision making in allocating scarcity of resources in the fulfillment of production activities and consumption activities in order to create a welfare in human life. 
Economics in the two main branches, namely microeconomics and macroeconomics. Microeconomics deals with the behavior of individual economic units including decision-making in order to overcome allocation problems due to resource scarcity. These units include consumers, workers or laborers, investors, landowners, core business firms of each individual or en titas play a role in the functioning of an economy. Microeconomics explains how and why this unit makes economic decisions. Another important area of microeconomics is how the economic units interact to form a larger unit of market and industry Case and Ray (1995: 9).

While macroeconomic branches, other major branches of the economy are concerned with issues of a macro or broader nature, including the number of economic aggregates such as the rate and growth rate of national production, interest rates, unemployment, and inflation. But the limitation between macroeconomics and microeconomics has been increasingly faded lately. Microeconomic analysis always begins with an understanding of institutions in economics including the law, which is able to explain producer behavior in allocating its resources. The producers are ultimately able to influence consumers in making decisions, but these consumers have limitations in making choices.

Islam teaches us how to manage consumption well so that there is a balance between income and expenditure. The reality we encounter today is that generally an employee or employee will look dying economically in the third weeks of each month. This is very closely related to our discussion this time, because it is very dependent on the behavior of these employees in managing their finances.

Consumption is a form of basic economic behavior in human life. In accordance with the word of Allah in Surat al-Nahal: 16 which reads:

And verily in the cattle there is really a lesson for you. We give you drink from what is in its stomach (in the form of) clean milk between the dung and the blood, which is easily swallowed for those who drink it (Q.S Al-Nahal: 16).

Economics in general, consumption is a person's behavior to use and utilize goods and services to meet the needs of life. In conventional economic theory the most important thing in consumption is how consumers allocate income to spend on products or services and explain the allocation decision in determining the demand desired by Sukirno (2009: 23).

Consumers will use satisfaction parameters through the concept of satisfaction (utility) which is reflected in the indifferent curve (the same level of satisfaction). Each individual seeks to fulfill his life needs through consumption activity at a maximum level of satisfaction using his income level (income) as a budget constraint. Islamic economic theory was born because of the theory of demand for goods and services. While demand for goods and services arise because of the desire (want) and the needs (need) by real consumers and potential consumers.

Humans are given freedom in conducting consumption activities in accordance with the rules that exist in Islamic teachings. In Islam not only regulate about worship and how to get closer to the creator, but also economic activity. The difference between modern economics and Islamic economics in terms of consumption lies in its approach to meeting the needs of everyone. Islam does not recognize a materialistic avarice solely from consumption patterns. 
According to Monzer Kahf (1995: 57) argued that the theory of consumption in Islam that aggregate consumption is one of the key variables in conventional economics. Aggregate consumption consists of consumption of basic necessities and consumption of luxury goods. Basic necessities (including for necessities of life and comfort) can be defined as goods and services capable of meeting a need or reducing life difficulties so as to make a real difference in the lives of consumers. Luxury goods alone can be defined as all goods and services desired both for self-pride and for something that does not really make a significant difference to the lives of consumers.

\section{Theoretical Review}

\section{History of Conventional Bank Economics}

In Babylonian times, Greece and Rome suspected banking business has played a role in trade traffic. The task of the bank at that time was more of a money exchange, so the person doing it was called the money merchant. In general, the work of money traders is only the intermediary exchange foreign currency with the currency of the country itself or vice versa. Then this business grows by accepting savings, entrusting, or lending money by levying interest on the loan.

Beginning of the establishment of banks in the World can be briefly described as follows. Approximately $2000 \mathrm{BC}$ in Babylonia has been known as a bank. The bank lends gold and silver at a rate of $20 \%$ per month and is known as Temples of Babylon. After Babylon's time, 500 BC following in Greece was established a kind of bank, known as the Greek Temple, which accepted deposits by charging its storage fees and lending it back to the public. It was then that the first private bankers appeared. Its operations include money changers and all kinds of bank activities. The first banking institution in Greece emerged in 560 BC.

\section{History of Bank Ekonomi Syariah}

The birth of the bank was originally the result of the development of the means of storing property. Merchants are worried about bringing jewelry and so on, moving from one place to another, while the thief's eye follows. Bank is a place that is trusted and maintained with the strength of energy because of the bank's guarding, general belief was attracted by it. Since then, the bank has developed in the way its merchandise. From this second move the bank system to western europe Ismail (2011: 31).

The Bank guarantees the deposit and can also use the deposit money by check, note money, and so on. The first bank stands from Venice and genua in Italy, sometime in the 14th century. The cities are familiar with the trading cities. Trade people by heading to these cities to exchange goods In pre-Islamic times there have actually been forms of trade that are now developed in the modern business world. Such forms include al-musharaka (joint venture), al-ba'iu takjiri (venture rance), al-ba'iu bitahman ajar (istalment sale), mortgage loans (al-murabahah), loans with additional interest ( usury). these forms of trade had developed in the Arabian peninsula, which was very strategic for the trade of that time, especially centered in the city of mecca, jeddah and the Arabian peninsula which was on the trade route between asia-africa-europe is most likely to have been influenced by the forms- the ancient form of egypt, ancient Greece and the roman about 2500 years before $\mathrm{AD}$ has known banking system as well as now the territory of Iraq also has known banking system familiar about 2000 years before mesehi this means since before Christ (banking system has grown and in need by 
humans in regulating the financing and payment system, and the banks are also prohibited to dispose of the money that is considered usury.

The Concept of Consumer Behavior

Some consumer behavior all leads to how to understand the actions consumers take in relation to the product. Consumer behavior is defined as the study of purchasing units and the exchange process that involves acquiring, consuming, and changing the goods, services, experiences, and ideas of Irham (2012: 2).

The American marketing association defines consumer behavior as a dynamic interaction of feelings, cognitions, behaviors and environments in which individuals exchange in various aspects of life Pater and Olson (2010: 5). The discipline of consumer behavior is one of the branches of social science; it utilizes research methods derived from the disciplines of psychology, sociology, economics, and antarapologi in researching human behavior as a consumer of Sumarwan (2004: 5).

Talking about personality becomes so unique and long and can not be excluded with the discussion of consumer psychology. Consumer reactions in deciding each product to be selected are all tailored to the convenience of the consumer's psychological. Personality differences applied to the behavior of consumers who are always trying to find satisfaction with himself with the desire to have the product on offer. According to Kotler (2005: 33), consumer satisfaction a feeling of pleasure or disappointment of someone who derives from the comparison between the impression of a product's results against those.

Everyone's stimuli see each object differently. These different differences give birth to multiple perceptions. Every perception everyone has can be very subjective and $i$ also considered as a reasonable. Conditions and situations in which a person is formed and influence the mindset that dimili by the person who further influences his assessment in seeing each product.

Consumers today are so smart because they get a variety of information received in various print and electronic media. It must be admitted if the existence of electronic media so great affects the formation of ploa thought someone in assessing each product. In other words information shaping changes the mindset of each person as well as builds a stimulus that ultimately shapes the perception in judging each product Irham (2012: 12).

Economics is a field of study on the management of material resources of individuals, communities, and countries to improve the welfare of human life. Because the economy is the science of human behavior and actions to meet the needs of life that varies and evolves with existing resources through the choices of production, consumption and or distribution activities. Sutarno (2011: 7)

Conventional economics is an event and problems related to the efforts of both individual and group human beings in meeting the unlimited needs with limited resources using economic theory described by the classical economic inventors such as Adam Smith. Generally speaking, the conventional economy is divided into two: capitalist and socialist. Sunarto (2011: 13). Capitalist economic system is an economic system that requires the freedom of each individual to do all economic activities without any government intervention. The socialist economic system is a stateregulated economic system. In this system the economy is fully the responsibility of a 
state or central government. This system has been widely used by countries in Eastern Europe that are communist.

Islamic economics as a science is born through a long process of scientific study. In the beginning there was a pessimistic attitude related to the Islamic excitement in the life of society today. This is due to the community has formed the idea that there must be inter-religious dichotomy and scholarship in this case including economics. Nur Rianto (2010: 18).

\section{Methods}

This research uses library research approach, because the object of study study is focused on the study by conducting a study on the books, data, literatures related to the analysis of research related to consumer behavior Sugiyono (2010). What is meant by literature research is a study of in-depth study of a paper in the form of books or other scientific papers that have or never been published Agung (1990: 9). Can also be nonscientific writing (fiction) which aims to examine more deeply about consumer behavior on the work of related fiction.

\section{Result and Discussion}

Result of Discussion on Consumer Behavior of Economics of Conventional and Sharia Economics

In this case the discussion of the household sector as a consumer in the output market. Will be seen how the way consumers behave, namely how he decides how much each item will be purchased in various situasai both consumer behavior nonmuslim and Muslim consumers. Islam is a perfect religion, which governs all human behavior in all its life. Islam regulates how humans should conduct their economic activities.

Various economic activities run in order to achieve a goal, namely creating a comprehensive welfare, full of tension and kesederharnaan, but still productive and innovative for every individual Muslim and non Muslim. Allah has set certain limits on human behavior so as to benefit individuals without sacrificing the rights of other individuals, as established by the law of Allah (sharia). Consumption, fulfillment (need), and the acquisition of pleasure are not forbidden by Islam for not $\mathrm{m}$ cause things that are not good or it can cause kemudratan.

The Equation of Consumer Behavior in Eonvesional Economics and Sharia Economics

First, the similarities between understanding consumer, consumer, and consumer behavior in conventional economics and Islamic economics are: (1) Consumption, both interpret as activities of using, reducing, or spending the benefit of a commodity goods or services available in the community in order to meet the needs.

(2) Consumers are equally defined as everyone who engages in consumption activities.

(3) Consumer behavior, both mean that consumer behavior is an action or behavior of consumer in using goods or services that aims to achieve prosperity.

Second, lies The similarity between conventional and Islamic consumer behavior is based on the view of each individual on the life of the world. Third, the motive and purpose of consumption. The equation lies in the existence of two motives for each consumer in behaving. The first motive is the internal motive derived from within the human itself (subjective) and the second motive is an external motive that comes from outside the human self (objective). As for the purpose of consumer consumption 
activities, in conventional economics and Islamic economics see the same purpose that is to meet the needs and maintain life.

Fourth, that is consumer behavior theory. In both conventional economics and Islamic economics, equivalent theories are related to increased consumer satisfaction (utility function), budget expenditure lines, and intertemporal consumption theory. Differences in Consumer Behavior in Conventional Economics and Sharia Economics

First, conventional economics views that the life of the world is an absolute right for man to live as freely as he pleases by achieving satisfaction without thinking that all that man obtains and uses is the creation of God. While in Islamic economics, human beings are taught to hold the view that the life of the world is based on the principles of monotheism, caliphate, and justice. Thus everything that man does always refers to the basis of accountability to the Creator.

Second, lies in the principle of consumption. In the conventional economic order, the principle that guides consumption activity is the principle of freedom, self interest, and materialistic. These three principles assume man as a rational economics man who has the freedom to govern his own fate based on desire and ability, every consumer is free to compete in fulfilling his needs, and every individual is free to satisfy his wishes without being tied to anyone. Contrary to that, the principle of consumption in the Islamic economy molds the human being as an Islamic man who highly upholds spiritual values, avoids martyrdom, israf and mudharat, and prioritizes the lawful and away from the unlawful. These principles include the principles of justice, the principle of cleanliness, the principle of simplicity, the principle of generosity, and the principle of morality.

Third, lies in the motive and purpose of consumption. There are two motives of consumption in both conventional economics and Islamic economics, that is, the motives derived from within man and the motives derived from outside the human self. Conventional consumer behavior driven by internal motives that aim to fulfill the needs of life and external motives that are more aimed at the fulfillment of desire lust. Whereas in the Islamic economy, the motive of a Muslim consumer in consuming is influenced by factors from within him who want to always live healthy and strong, and the motive from outside himself is a form of desire to meet the need for comfort and sociologically want to get a positive assessment of others or the public . While the purpose of consumption in conventional economy besides to fulfill the necessity of life, consumer also aim to fulfill the level of satisfaction maximally, pursuing social status and prestige oriented to prestige in order to get praise in life in the middle of society. While the purpose of Muslim consumers to meet their needs materially is to bring physical health, maintain and close aurat, as well as provide comfort to life. And his spiritual purpose is in order to form a thankful soul and to strengthen his faith in Allah SWT.

Fourth, In conventional economics, the need is determined by the concept of satisfaction (utility) so that the division of needs is divided based on the level of intensity, nature, subject that requires, and time. According to the intensity of its use, needs can be divided into primary, secondary, and tertiary needs. By nature, needs consist of physical needs and spiritual needs. According to the subject of need, the need is differentiated into the needs in dividual and general needs. According to the time, needs are differentiated into present needs and future needs. Whereas in the Islamic 
economy the needs are determined by the concept of maslahah which divides the needs into three, namely the needs of dharuriyah, hajjah needs, and tahsiniyah needs.

Fifth, conventional consumer behavior theory gives the view that every consumer is always willing to spend his income to obtain some goods and services because the goods and services are useful and can increase the level of satisfaction. While in the theory of Muslim consumer behavior, it is very important that the distribution of goods and services between the haram and the halal.

When conventional economics assumes that consumers are always aiming for maximum satisfaction, this will certainly lead to much critical analysis, especially when viewed in the viewpoint of Islamic law. The comparisons between consumer behavior in conventional economics and Islamic economics that have been described above, explain that there are some differences from both points of view. The first is lies in the cornerstone of the philosophy of consumer behavior. In the conventional economic perception, the life of the world is regarded as an absolute right for human so that this understanding causes human beings to prefer the rational side in using the existing resources so as to override the moral side. Second, related to the principle of consumption. The principle of consumption in the conventional economy there are three namely freedom, self interest, and material. Third, look at the motive and purpose of consumption. The internal motive of conventional consumption is due to the desire for goods and services, because goods and services can be useful for the fulfillment of life needs and external motives more due to the desire to meet the lust.

The purpose of consumption in conventional economy besides to fulfill the necessity of life, consumer usually also aim to fulfill the level of satisfaction maximally, pursuing social status and prestige oriented prestige. Fourth, lies in the configuration of consumer needs. Consumer needs in conventional economics are divided into needs according to the level of intensity, nature, subject that requires, and according to time. Fifth, which lies in the theory of consumer behavior. In the theory of conventional consumer behavior, each consumer will spend his income to obtain some goods or services because of its usefulness that can increase the level of satisfaction. Further related to the theory of budgetary constraints,

In a conventional economy when the consumer wants to choose the commodity of a good or service, they simply take into account the large number of combinations of goods obtained from the total expenditure utilization. In the view of sharia, this is strictly prohibited and prohibited if it is continuously sustainable. For not only will rule out ethics, but when consumption is conventionally always applied it will damage the moral and bad for human life.

Meanwhile, another alternative that is justified and recommended to always be applied is consumer behavior based on Islamic teachings, which refers more to prosperity. Islam teaches that the life of the world is based on the principle of accountability to the Creator so that people are forbidden to act as they please. Inculcate the motive in each individual so that consumption is done on the basis of the desire to always live healthy and strong, then cultivate an external motive as a form of desire to meet the need for comfort and sociologically want to get a positive assessment of others.

Consumption aimed not only to bring physical health, close the aurat, provide comfort life, but also become a means in shaping the soul thankful and strengthen the Faith to Allah SWT. Putting aside the need for substitutes and prioritizing the needs of 
the needs of dharuriyah, hajiyah, and tahsiniyah. And the last is the theory of consumer behavior, the division of goods or services that are haram and the halal must be a top priority When Muslim consumers are faced with several choices of combinations of goods or services to be consumed, he will use his total spending to choose more commodities into his main needs and this election is always based on sharia values.

\section{Conclusion}

After writing review and analyze about the comparison of consumer behavior in conventional economic and economic perspectives of sharia then it can be concluded that: (1) Consumer behavior involves the behavior of consumers, where they can illustrate searches to buy, use, evaluate and improve their products and services. The focus of consumer behavior is how individuals make decisions to to use their existing resources to consume goods and services. (2) At a certain level of opinion, Islamic consumers, for choosing the allocations for things concerning the afterlife, will consume fewer items than non-Muslims. The limiting thing is the concept of the problem mentioned above. Not all goods and services that provide satisfaction / utilitiy contain problems in it, so not all goods and services can and feasible consumed by Muslims. (3) The similarity between consumer behavior in carrying out consumption activity in conventional economy and Islamic economy there are three. Among them in terms of understanding, the foundation of philosophy, the motive and purpose of consumption, as well as the theory of consumer behavior. Meanwhile, differences in consumer behavior in conventional economics and Islamic economics are first, conventional economics views that the life of the world is an absolute right for man while Islamic economics teach that the life of the world is based on the principle of accountability to the Creator. Second, lies in the principle of consumption. The principle of consumption in the conventional economy there are three namely freedom, self interest, and material. Third, the motive and purpose of consumption. (4) In conventional economics, the internal motive of consumption is for the fulfillment of the necessities of life and the external motive is more aimed at fulfilling the desires of the lust. While the internal motive in the consumption of Islam is to always want to live healthy and strong, then the external motive is a form of desire to meet the needs of comfort and sociologically want to get a positive assessment of others.

\section{REFERENCES}

Amalia (2012). Microeconomic Theory, PT Fajar Interpratama Mandiri, Jakarta.

David L. Loudon and Albert J. Della Bitta (1984). Consumers, Edition 10. Jakarta.

Amalia, Euis (2010). Conventional Economy. Jakarta: Prenamedia Group

Fahmi, H (2011). Consumer Behavior, Bandung.

Ismail (2011) Syariah Banking. Jakarta: Pustaka Al-Husna.

Juhaya, H. and Pradja, S (2012) Sharia Economics. Bandung: CV Pustaka Setia.

Kahf, M., (1995) Islamic Economics. Yogyakarta: PustakaPelajar.

Karim. A. Ir. (2007). Micro-Islamic Economics. third edition. Rajawali Press. Jakarta. 
Marton. Saad. Said. (2004). Islamic Economy Amid Global Economic Crisis. Zikrul Hakim. Jakarta.

Mamang. S. (2011). Consumer Behavior. CV Andi Offset. Yogyakarta.

Metwally. (1995). Theory and model of Islamic economics. PT Bangkit Daya Insana. Jakarta.

Nasution. M.E.. Huda. N. et al (2006). The Exclusive Introduction of Islamic Economics. Kencana Prenada Group. Jakarta.

Nur. (2011). Microeconomic Theory. PT Fajar Interpratama Mandiri. Jakarta.

Rahardja. P. and Mandala. M. (2004). Microeconomic Theory: An Introduction. third edition. FE UI Publishing Agency. Jakarta.

Rianto. M. (2010). Sharia Economics: Theory and Practice CV Loyal Pustaka. Bandung.

Rianto. N. And Amalia. E. (2012). Mekroekonomi Theory. First Edition. Prenadamedia Group Publisher. Jakarta.

Schiffman and Kanuk. (2008). Consumer Behavior Edition 7. Jakarta: Index.

Schiffman. L and Kanuk. L. (2004). Consumer Behavior. Second Edition. New York.

Sukirno. S.. (2009). Micro Economics: Introduction Theory. third edition. Rajawali Pers. Jakarta.

Sumarwan. U. (2004). Consumer Behavior: Theory and Its Application in Marketing. Second Edition. Bogor.

Setiadi S. and Nugroho. (2012). Consumer Behavior. Jakarta: Airlangga

Sopiah. (2011). Consumer Behavior. Yogyakarta: Bharata

Yuniarti. S. (2010). Macro Economy Syariah. CV Pustaka Setia. Bandung.

Von Peter Schmiedel. (2010) Sharia Economics. Bandung: Loyal Reader. 2010.

Usman S. (2011). Perbank Syariah. Jakarta: Al-Husna 